\title{
$\begin{array}{lllllllll}\text { I } & \mathrm{N} & \mathrm{S} & \mathrm{T} & \mathrm{I} & \mathrm{T} & \mathrm{U} & \mathrm{T} & \mathrm{E}\end{array}$
}

\section{Rural Youth are More Likely to be Idle}

\author{
ANASTASIA SNYDER AND DIANE MCLAUGHLIN
}

A pproximately 10 percent of young adults (aged 18-24) today are idle, that is, they are not in postsecondary school, the workforce, or the Armed Forces. ${ }^{1}$ Among high school dropouts the shares are even higher, at 30 percent. Idle youth are not following the typical pathways from adolescence to adulthood. They are not gaining adequate educations, are not gaining work experience, and they have no obvious sources of earned income. ${ }^{2}$

Table 1. Percentage Idle among All Youth Aged 18-24 In RUral ANd Urban Areas, 2006*

\begin{tabular}{llll} 
& OVERALL & URBAN & RURAL \\
\hline All 18-24 year olds in 2006 & $\mathbf{1 0 . 4}$ & $\mathbf{1 0}$ & $\mathbf{1 2 . 4}$ \\
\hline SEX & & & \\
\hline Male & 11 & 10.4 & 14 \\
Female & 9.7 & 9.6 & 10.5 \\
RACE/ETHNICITY & & & \\
\hline Non-Hispanic White & 8.1 & 7.5 & 10.5 \\
Non-Hispanic Black & 14.4 & 14 & 16.5 \\
Hispanic & 14.8 & 14.5 & 19.3 \\
Other & 11.7 & 10.3 & 22.6 \\
FAMILY POVERTY RATIO & & & \\
\hline Less than 1.0 (below poverty) & 19.2 & 18.7 & 21.2 \\
1.0-1.5 & 15.1 & 14.2 & 18.7 \\
\hline Greater than 1.5 & 7.7 & 7.5 & 8.6 \\
REGION & & & \\
\hline Northeast & 8.9 & 8.8 & 9.2 \\
\hline Midwest & 8.6 & 8.5 & 8.9 \\
\hline South & 11.6 & 10.9 & 14.2 \\
West & 11.5 & 10.1 & 18.4 \\
EDUCATION** & & & \\
\hline In or Completed High School & 7.7 & 7.3 & 9.7 \\
High School Drop Out & 29.2 & 28.7 & 31.3 \\
\hline
\end{tabular}

Source: 2006 March Current Population Survey. Data are weighted to adjust for sample design using the standardized person weight. Some CPS respondents are not classified as metropolitan or nonmetropolitan, these are included in the overall figures but not in area-specific figures.

* Sample reflects 18,311 youth aged 18-24 (3,512 in nonmetro/rural areas; 14,610 in metro/urban areas).

$* * 2,228$ youth in the sample are 18 or 19 years old and still in high school (509 in nonmetro/rural areas; 1,694 in metro/urban areas).
Higher shares of rural (12.4 percent) than urban youth (10.0 percent) are idle. (See Table 1$).^{3}$ The differences also vary by gender, race-ethnicity, family poverty, region, and education level. Rates of idleness among racial-ethnic minorities in rural areas are particularly high-16.5 percent of rural blacks, 19.3 percent of rural Hispanics, and 22.6 percent of rural "other" racial-ethnic groups (such as American Indians) are idle. All groups fare less well than their urban counterparts, but the largest rural-urban distinction is among the "other" racial-ethnic group, with a gap of 12.3 percentage points between urban and rural youth in this racial-ethnic category.

Differences in the levels of idleness between rural and urban areas are relatively small in the Northeast and Midwest, but considerably larger in the South and largest in the West. In the West, 18.4 percent of rural youth and 10.1 percent of urban youth are idle.

\section{Three Times as Many High School Dropouts are Idle}

Education is a critical factor in idleness. Young adults who dropped out of high school are three times as likely to be idle as their peers who graduated. For example, among those who completed high school 7.7 percent were idle in 2006 compared to 29.2 percent of those who dropped out of high school. These large percent differences in idleness by high school completion exist in both rural and urban areas.

Table 2 focuses our attention on rural/urban differences in idleness by high school completion, and how this varies by sex, race/ethnicity, family poverty and region. Although poverty, minority status, and living in the Northeast are risk factors for idleness among all youth, the risk to high school dropouts is even higher for rural youth. Nearly one-half of rural non-Hispanic blacks who have dropped out of high school are idle, as are nearly one-half of young adult dropouts from low-income families. Likewise, 45 percent of rural high school dropouts in the Northeast are idle (Table 2). The exceptions to higher idleness among rural than urban high school dropouts are among females, Hispanics, and families with incomes above poverty levels. In each case, urban high school dropouts have higher rates of idleness than rural youth.

\section{CARSEY I N S T I T U T E}

BuILding KNOWLEDGE FOR Families And Communities
Huddleston Hall, 73 Main Street, Durham, NH 03824

(603) 862-2821 • www.carseyinstitute.unh.edu

The Carsey Institute Reports on Rural America are supported by the Annie E. Casey Foundation's initiative to strengthen rural families, the Ford Foundation, and the W.K. Kellogg Foundation. 


\section{Policies and Programs Are Needed to Put Young Adults Back on Path to Productivity}

Idleness among young adults is a serious problem, particularly among those who have dropped out of high school, nearly one-third of whom were idle in 2006. Although there have been steady declines in dropouts in recent decades, education policies to reduce school dropout rates and to re-enroll those who have dropped out of high school are needed. With current education policy focused on improving standardized test scores, it is understandably difficult for schools to direct resources toward students who are at risk of dropping out. However, a broader and longer-term perspective is required. The path these youth follow into adulthood affects the likelihood of their success as adults. Being idle means that life as a productive member of society is delayed, or never attained. Job training programs that provide marketable skills and include GED equivalency would offer these young adults a second chance.

Racial and ethnic disparities in idleness suggest the need for programs that focus on schooling and employment for these minority youth. One-half of rural black high school dropouts, but only 12 percent of rural blacks who completed high school, are idle. This large difference suggests unique barriers facing black youth in rural schools and labor markets, largely in the South. In contrast, idleness among rural Hispanics is quite similar across levels of educational attainment, which likely signals the higher demand in some local rural labor markets for workers with less education and lower skills.

Finally, variation in idleness across rural and urban areas and by region signals the importance of local and regional education systems and labor markets in reducing idleness. Special attention is needed for policies affecting schools and employment opportunities in areas with the highest levels of idleness, and these are in rural areas

This fact sheet provides only a snapshot of young adult idleness. Future and more detailed Carsey Institute reports will look into the factors that lead to idleness, those that help idle youth to become reengaged, and the barriers to engagement after a spell of idleness.

\section{A U T H O R S}

Anastasia R. Snyder is an Associate Professor of Human Development and Family Science at Ohio State University (asnyder@ehe.osu.edu).

Diane K. McLaughlin is an Associate Professor of Rural Sociology and Demography at Penn State University (dkk@ psu.edu).

\section{E N D N O T E S}

${ }^{1}$ Youth are considered idle if they are not in school, the labor force (employed or unemployed), or the Armed Forces.
TAble 2. Percentage Idle by High School Completion for

Youth Aged 18-24 In Rural AND Urban AreAs, 2006

\begin{tabular}{|c|c|c|c|c|c|c|}
\hline & \multicolumn{2}{|c|}{ OVERALL } & \multicolumn{2}{|c|}{ URBAN } & \multicolumn{2}{|c|}{ RURAL } \\
\hline & $\begin{array}{l}\text { Completed } \\
\text { High School }\end{array}$ & $\begin{array}{l}\text { High School } \\
\text { Drop Out }\end{array}$ & $\begin{array}{l}\text { Completed } \\
\text { High School }\end{array}$ & $\begin{array}{l}\text { High School } \\
\text { Drop Out }\end{array}$ & $\begin{array}{l}\text { Completed } \\
\text { High School }\end{array}$ & $\begin{array}{l}\text { High School } \\
\text { Drop Out }\end{array}$ \\
\hline $\begin{array}{l}\text { Idleness among 18-24 } \\
\text { year olds in } 2006\end{array}$ & 7.7 & 29.2 & 7.3 & 28.7 & 9.7 & 31.3 \\
\hline \multicolumn{7}{|l|}{ SEX } \\
\hline Male & 8 & 31.7 & 7.5 & 30.7 & 10.3 & 36.6 \\
\hline Female & 7.5 & 26.2 & 7.2 & 26.6 & 9 & 23 \\
\hline \multicolumn{7}{|l|}{ RACE/ETHNICITY } \\
\hline Non-Hispanic White & 6.3 & 28.3 & 5.9 & 27.3 & 8.1 & 31 \\
\hline Non-Hispanic Black & 10.7 & 39 & 10.2 & 38.4 & 12.2 & 49.9 \\
\hline Hispanic & 10.4 & 25.6 & 10 & 25.9 & 18 & 21.5 \\
\hline Other & 9.4 & 35.6 & 8.2 & 34.7 & 20.1 & 36.3 \\
\hline \multicolumn{7}{|l|}{ FAMILY POVERTY RATIO } \\
\hline$<1.0$ (below poverty) & 12.8 & 42.2 & 12.5 & 40.6 & 13.8 & 48.5 \\
\hline $1.0-1.5$ & 12.1 & 28.4 & 10.9 & 28.9 & 16.9 & 27.2 \\
\hline Greater than 1.5 & 6.2 & 22.4 & 5.9 & 22.7 & 7.5 & 20.5 \\
\hline \multicolumn{7}{|l|}{ REGION } \\
\hline Northeast & 6.2 & 31.5 & 6.2 & 30.3 & 5.7 & 45 \\
\hline Midwest & 6.3 & 27.9 & 6.3 & 27.1 & 6.4 & 30.5 \\
\hline South & 8.7 & 28.7 & 8.1 & 28.4 & 11.3 & 29.3 \\
\hline West & 8.8 & 29.5 & 8.1 & 29.3 & 17.2 & 32.1 \\
\hline
\end{tabular}

${ }^{2}$ Data are drawn from the Annual Social and Economic Supplement (ASE) of the 2006 Current Population Survey (CPS). The 2006 supplement sampled 97,352 U.S. households and is the main source of information on the U.S. labor force. We use the 2006 ASE CPS to calculate national estimates of idleness for youth and how levels of idleness vary by key demographic characteristics in rural/nonmetro and urban/metro areas.

${ }^{3}$ The CPS uses nonmetropolitan and metropolitan distinctions rather than rural and urban. Therefore, we use rural/nonmetro and urban/metro interchangeably in this fact sheet. Metropolitan is a county-level classification based largely on population size created by the U.S. Office of Management and Budget. Metropolitan counties must have a large population center of at least 50,000 residents and a total population of 100,000 (75,000 in New England). Counties without large population centers that are adjacent to metropolitan counties may be considered metropolitan if they have economic ties to metropolitan counties as evidenced by the percentage of the workforce commuting to the central metropolitan county. Nonmetropolitan counties are those that are not classified as metropolitan. For more information visit: http://www.census.gov/population/www/ estimates/metroarea.html. 